\title{
LIETUVOS RELJEFAS KARTOGRAFINIUOSE DOKUMENTUOSE
}

\author{
Romualdas Girkus ${ }^{1}$, Viktoras Lukoševičius ${ }^{2}$ \\ ${ }^{1}$ Aerogeodezijos institutas, Pramonès pr. 13, LT-51327 Kaunas, Lietuva, el.paštas: info@agi.lt \\ ${ }^{2}$ Kauno technologijos universitetas, Panevéžio institutas, Klaipédos g. 1, LT-37348 Panevéžys, Lietuva, \\ el.paštas:vikluk@midi.ppf.ktu.lt
}

Iteikta 200502 14, priimta 20050707

\begin{abstract}
Santrauka. Pateikta skirtingose Lietuvos žinybose dirbusių specialistų - miškininkų, kelininkų, geografų, topografų, hidrografų, žemėtvarkininkų ir geoinformatikų i̇vairaus laikotarpio Lietuvos reljefo interpretacijos. Aptariami svarbiausieji Lietuvos reljefą apibūdinantys, pastarojo šimtmečio kartografiniai produktai. Analizuojama Lietuvos reljefo vaizdavimo raida, pateikiama jos kokybinès ir technologinès charakteristikos. Šiek tiek pateikiama informacijos apie kartografinių produktų autorius.
\end{abstract}

Raktažodžiai: topografiniai žemèlapiai, reljefo modelis, izohipsès, morfografinis žemèlapis, geoinformacinė duomenų bazè.

\section{Ivadas}

Lietuvos Žemès paviršiaus atvaizdavimo metodai istoriniais laikotarpiais kito, stengtasi Žemès paviršiaus formas teikti kuo vaizdžiau ir tiksliau. Senuosiuose žemėlapiuose kalnai buvo atvaizduojami profiliniais kalnų piešiniais. 1718 m. H. J. Baptista (1663-1724) pirmą kartą kalnų šlaitus pavaizdavo plonais radialiniais brūkšneliais. Šis metodas paplito XVIII a. viduryje, o XIX a. pradžioje pripažintas visuotinai. XVIII a. pabaigoje Saksonijos kartografas J. G. Lèmanas (17651811) reljefui atvaizduoti pasiūlè štrichavimo metodą, pagrịstą paviršiaus apšvietimo dėsniu, statumą išreiškiant linijomis. Šis metodas žinomas reljefo brūkšniavimo pavadinimu [1]. Horizontalių metodas pirmą kartą taikytas Prancūzijos topografinei nuotraukai, kuri buvo atliekama 1730-1780 metais. Izohipsių juostos pirmą kartą skirtingomis pereinamosiomis spalvomis buvo nuspalvintos 1835 metais Skandinavijos M 1:500 000 žemėlapyje [2]. Vaizdžiausia reljefo išraiškos forma laikytinas reljefo modelis. Reljefo modelių istorija susijusi su jų mechanine gamyba. Skaitmeninès technologijos laikotarpiu reljefo modeliuose reljefas interpretuojamas spalvine skale, spalvų intensyvumu, imituojant šlaitų apšvietimą ir pan.

\section{P. Matulionis ir jo reljefo modelio istorija}

Pirmuoju Lietuvos reljefo modelio sudarytoju laikytinas Povilas Matulionis (1860-1932). P. Matulionis po Pirmojo pasaulinio karo 1918 m. sugrižo i Lietuvą iš Smolensko ir iki $1921 \mathrm{~m}$. vadovavo miškotvarkos darbams bei Lietuvos miškų departamentui. Kai buvo sudaromas modelis, dirbo dèstytoju Dotnuvos žemès ūkio technikume ir Kauno Vytauto Didžiojo universitete, o 1924 m. tapo pirmuoju Žemès ūkio akademijos rektoriumi [3]. Jo sudarytas reljefo modelis „Lietuvių ir latvių žemë“ $1922 \mathrm{~m}$. Smolenske ,Vilijos“ fabrike buvo išlietas iš gipso (1 pav.). Reljefo modelio $45 \times 49 \mathrm{~cm}$ stačiakampis apima lietuvių ir latvių istorines žemes ir jų pakraščius. Reljefo modelio horizontalusis mastelis 1:1 260000 , vertikalusis - 1:10 000. Modelio apraše autoriaus parengtoje knygelèje „Lietuvių ir latvių žemë“ nurodomos modelio kraštu dienovidinių nuo Grinvičo ir lygiagrečių geografinès koordinatès. Modelyje jos išbrèžtos ir reikšmès pažymètos kas $1^{\circ}$. Knygelèje išvardyti modelyje atvaizduoti kalvynai (tekste „kalnujos“), nurodomi žymiausių viršukalnių aukščiai metrais virš jūros lygio. Pateikiama duomenų apie svarbesnes upes, ju ištakų aukščiai virš jūros lygio bei upių ilgiai kilometrais. Teikiamas tik bendras ežerų plotas - hektarais kalnyne ir ežerų skaičius, jų neįvardijant. Deja, kalvų ir upių šios skaitmeninès reikšmès bei vardai modelyje nelokalizuoti. Skurdžiausia informacija apie ežerus, nes neišvardyti net didžiausieji ežerai su jų lygio aukščiais virš jūros lygio. Informacija apie bendraji ežeru plotą ir skaičių autoriaus imta iš Žuvininkystès įstaigos bei E. Nonevičiaus darbų [4]. 


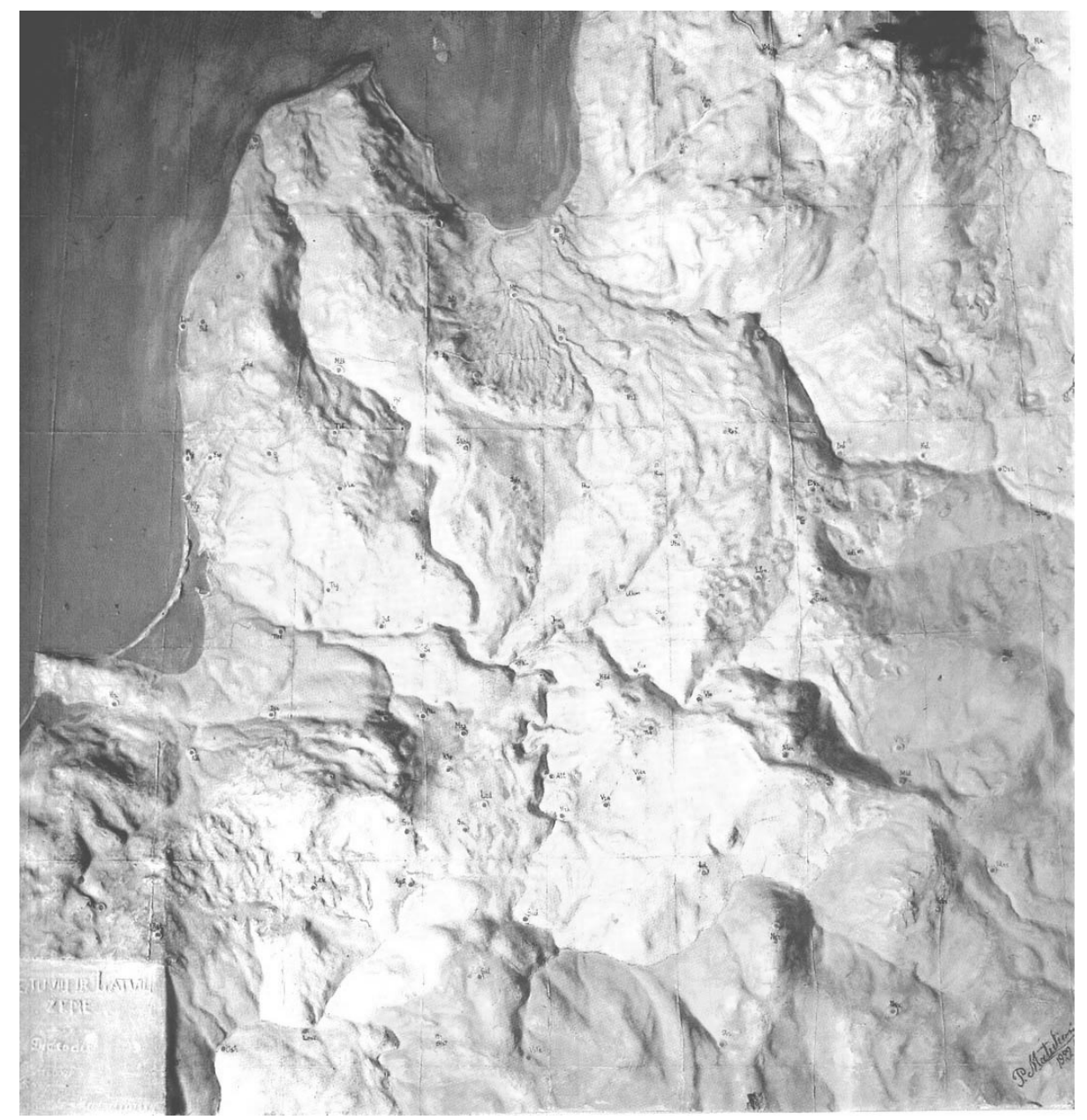

1 pav. Lietuvos ir Latvijos reljefo modelis. Horizontalusis mastelis - 1:1 260 000, vertikalusis - 1:10 000. P. Matulionis. Gipsas

Fig 1. Relief model of Lithuania and Latvia. Scale of area - 1:1 260000 , scale of elevation - 1:10 000. Made by P. Matulionis. Plaster

Tautu etnografinès žemès (lietuviu, latvių, estų, rusų, gudu, lenku, vokiečiu) modelyje išskirtos spalvomis. Mèlynoje jūros teritorijoje pažymèta Latvijos Ruhnu sala ir isiterpianti Estijos Saaremos salos dalis. Tenka apgailestauti, kad jūros teritorijoje net spalviniu intensyvumu neišskirtas dugno reljefas.

Reljefo sąsajai su vietove dèl užrašų, susijusiu su hidrografija ar reljefu, stokos raudonais puansonais pažymèti 88 miestai, pateikti jų vardų trumpiniai. Tenka pastebėti, kad modelyje Anykščiu vietoje pažymèta Utena.

Autorius knygelëje bendrais bruožais aprašo ir modelio gaminimo procesa. Modelio teritorija buvo suskaidyta kas 30' stačiakampiais, sudarytieji skardžiu profiliai išpjauti medinèse lentelèse. Tose lentelèse buvo formuojami keturkampiai gardeliai su „pragardemis“. Tarpai tarp sujungtų profilių buvo užpildomi lydytu bičiu vašku. Paviršiaus reljefas formuotas iš gipso.

Lietuvos reljefo modelis eksponuotas kartu su žemélapiais 1999 ir 2003 m. Lietuvos nacionalinio muziejaus surengtose parodose „Lietuva žemèlapiuose” [5]. Dar vienas šio reljefo modelio egzempliorius yra išlikęs iš Kèdainių kultūrtechnikos mokyklos (ikurta 1927 m.), ruošusios ir matininkus, laikų. Antrojo pasaulinio karo metu, nors mokyklos pastatas buvo sugriautas, apgadintas, reljefo modelis išliko ir buvo perduotas Kaune ikurtam Žemès ūkio technikumui, kuris rengè ir topografus. Iki $2003 \mathrm{~m}$. modeli saugojo šio technikumo dèstytojas P. Balašaitis. Vèliau reljefo modelis perduotas Aerogeodezijos institutui, jo lešomis restauruotas Lietuvos nacionalinio muziejaus restauravimo dirbtuvèse ir papildè šio instituto žemèlapių ekspozicija.

\section{P. Matulionio reljefo modelio šaltiniai}

Pagrindiniu šaltiniu laikytinas P. Matulionio 19181920 m. sudarytas „Kalnuotumo ir nuotakumo Lietuvos ir jos pakraščiu žemėlapis su žymesnèmis apgyvendintomis vietovėmis“, M 1:630 000 (2 pav.) [6]. Tai teigtina, nes modelio mastelis lygiai du kartus smulkesnis už žemėlapio. Antrasis ši teigini patvirtinantis faktas yra tai, kad žemèlapio teritorija su nežymiais poslinkiais adekvati modelio teritorijai, net žemélapio ir modelio legendų vietos yra adekvačios. 


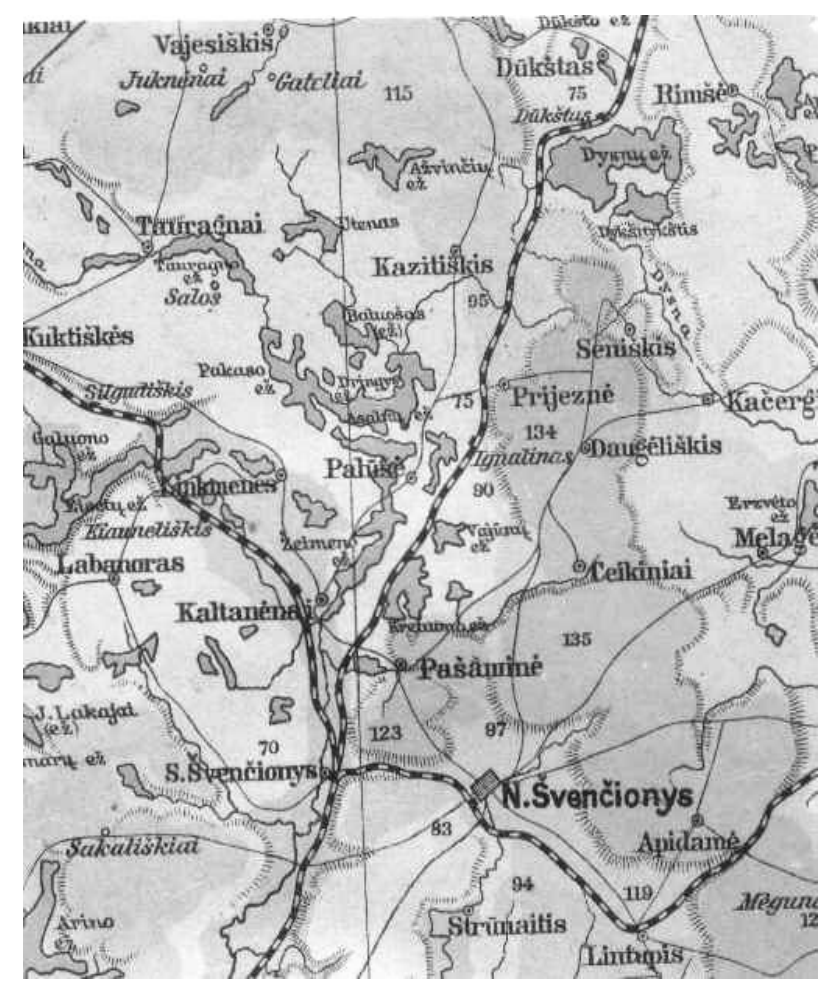

2 pav. Lietuvos ir jos pakraščiu kalvotumo bei nuotakumo M 1: 630000 žemèlapio fragmentas

Fig 2. Map of upland and slope of relief of Lithuania and border zone. 1: 630000

Žemėlapyje reljefas buvo atvaizduotas spalvinėmis juostomis 30 sieksnių laiptu (1 sieksnis $-2,1336 \mathrm{~m}$ ), o išsiskiriančių kalvynų ribos - radialiniais brūkšneliais su aukštumų ir kalvų žymomis, teikiant skaitmenines aukščiu virš Baltijos jūros lygio reikšmes. Tenka pažymèti, kad knygelès prie modelio priede informacija apie reljefą pateikiama jau pagal metrinę sistemą.

Reljefo modeliui paruošti naudoti ir to laikmečio smulkesnių mastelių rusų ir vokiečių topografiniai žemèlapiai [4]. Reikia priminti, kad 1913 metais Paryžiuje tarptautineje geografų konferencijoje buvo nutarta bendromis valstybių jëgomis ir lëšomis kurti milijoninio mastelio tarptautini žemèlapi. Lietuvos teritorija pateko i 4 žemėlapio lapus, kuriuos turèjo parengti kaimyninès valstybès. P. Matulioniui sudarant reljefo modeli jie dar nebuvo išleisti. Pirmaji iš jų $-N N$ 34 Warsawa - 1926 m. išleido lenkai, o 1929 m. pakartojo vokiečiai, pakeitę pavadinimą Ostpreussen, antraji - NO-34 Stockholm -1928 m. išleido švedai [7].

\section{Susisiekimo ministerijos hipsometrinis žemèlapis}

M 1:300 000 žemèlapio autorinis originalas sudarytas Hidrometrijos biure, kuriam vadovavo S. Kolupaila [8]. Jis buvo šio vadinamojo „Lietuvos upiu ir jos baseinų hipsometrinio ir hidrografinio žemèlapio“" redaktorius, o sudarytojas - biuro darbuotojas S. Mižutavičius. Žemèlapis apima teritoriją ir ỉ rytus bei pietus už Lietuvos ribų besitęsiančias aukštumas. Žemèlapiui sudaryti panaudota turima kartografine M 1:84 000 (rusu) ir M 1:100 000 (vokiečiu) medžiaga, pažymint didesnius vietovès pokyčius ir lietuvinant vietovardžius. Reljefas pavaizduotas horizontalèmis kas $20 \mathrm{~m}$ ir hipsometrinès skalès spalvinèmis juostomis kas $40 \mathrm{~m}$, jūros dugnas išreikštas izobatèmis $-5,10,20$ ir t. t. metru gylio. Žemèlapis parengtas 1930 metais, tačiau liko neatspausdintas. Išlikęs originalas restauruotas ir saugomas Aerogeodezijos institute.

Žemèlapis L. Mindaugo (S. Mižutavičius pakeitè pavardę) pertvarkytas i M 1:1 $000 \quad 000$, per visą kartografuotą plotą sumažintas rytu ir pietu kraštinèmis iki Lietuvos sienu ir $1943 \mathrm{~m}$. Vandens valdybos Hidrografijos skyriaus išleistas pavadinimu „Lietuvos upių baseinu hidrografinis žemėlapis“ (fragmentas 3 pav.).

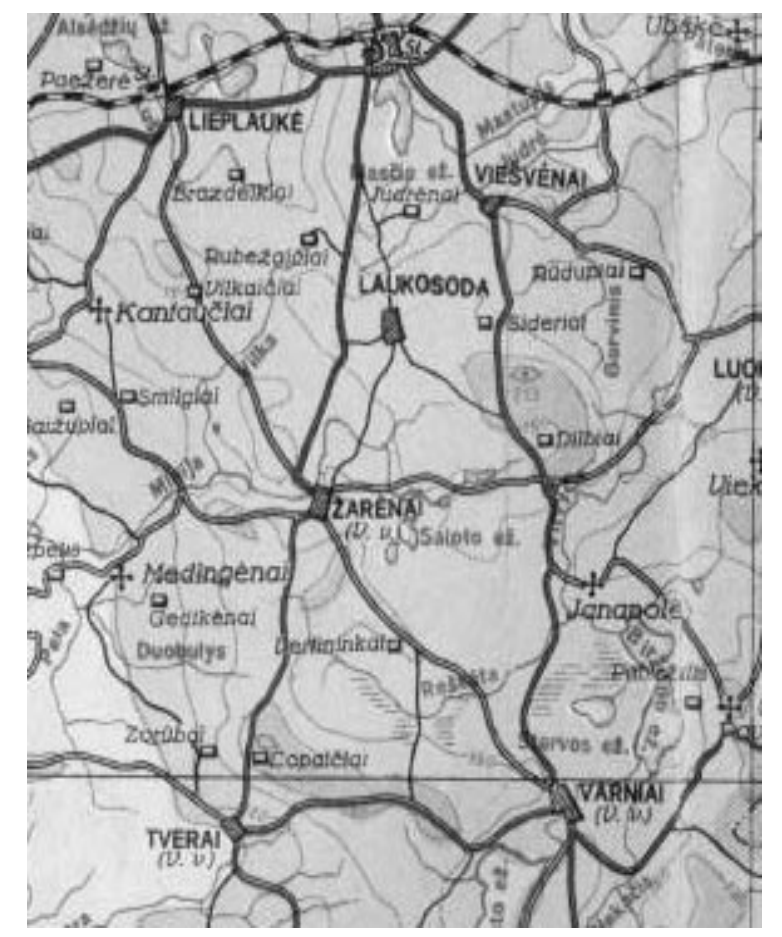

3 pav. Lietuvos upių baseinų hidrografinio M 1:1 000000 žemèlapio fragmentas

Fig 3. Fragment of hidrographic map of river basins of Lithuania. 1:1 000000

\section{Karo topografijos skyriaus žemėlapis}

Tai Lietuvos krašto apsaugos ministerijos Vyriausiojo štabo $1933 \mathrm{~m}$. M 1:400 000 leidinys - du sugretinami lapai (4 pav.). Lietuvos teritorijos žemèlapis sudarytas pagal buvusią rytinę sieną, $1920 \mathrm{~m}$. patvirtinus sutarti su sovietų Rusija. Jame Lietuvos paviršiaus aukščiu skirtumai išreikšti horizontalèmis kas $20 \mathrm{~m}$, o Baltijos jūros šelfe - izobatemis kas 10 m, Kuršiu mariose - kas $2 \mathrm{~m}$. Žemèlapis išleistas penkiu modifikacijų, trys iš jų - su reljefu:

- A serijos 5 spalvų žemėlapyje žemumų plotai iki $20 \mathrm{~m}$ virš jūros lygio ir nuo 20 iki $60 \mathrm{~m}$ nuspalvinti žalia ir žalsva spalvomis, kiti 4 reljefo sluoksniai - po $60 \mathrm{~m}$ dèl sluoksnių aukščio - tamsèjančiomis rudomis spalvomis. Kadangi spaudos spalvinè skalè skirta krašto 


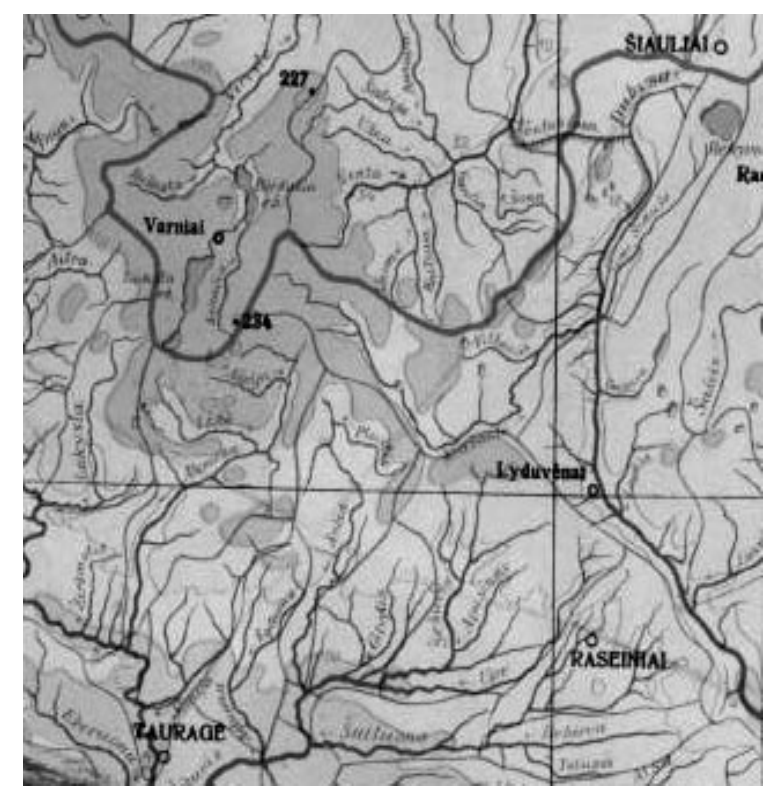

4 pav. Lietuvos M 1:400 000 žemèlapis, $1933 \mathrm{~m}$.

Fig 4. Map of Lithuania, 1:400 000, 1933

hipsometrijai, tai tradiciškai žaliai vaizduojami miškai neišskirti.

- B serijos 5 spalvų žemèlapis - su visais tradiciniais vietovès elementais ir horizontalemis kas $20 \mathrm{~m}$;

- E serijos dvieju spalvų žemèlapis skirtas tik hidrografijai ir reljefui (reljefas atvaizduotas horizontalèmis).

Sudarant žemėlapi naudotasi rusų M 1:84 000 ir vokiečių M1:100 000 lapais, nes lietuviškas M 1:100 000 žemèlapis tebuvo pradètas rengti.

\section{Kelininkų pagamintas Lietuvos reljefo modelis}

Apie antraji Lietuvos reljefo modeli težinome tik iš to laikotarpio leidinio ,Žemaičių plentas - 1939“. Šiame kelių autorių - L. Tuskenio, A. Baranausko, A. Tamašausko ir A. Butavičiaus jubiliejiniame leidinyje [9] buvo išspausdinta Lietuvos reljefo modelio $M \approx 1: 2 \quad 000 \quad 000$ fotografija. Lietuva šiame modelyje jau be vokiečiu okupuoto Klaipėdos krašto (5 pav.).

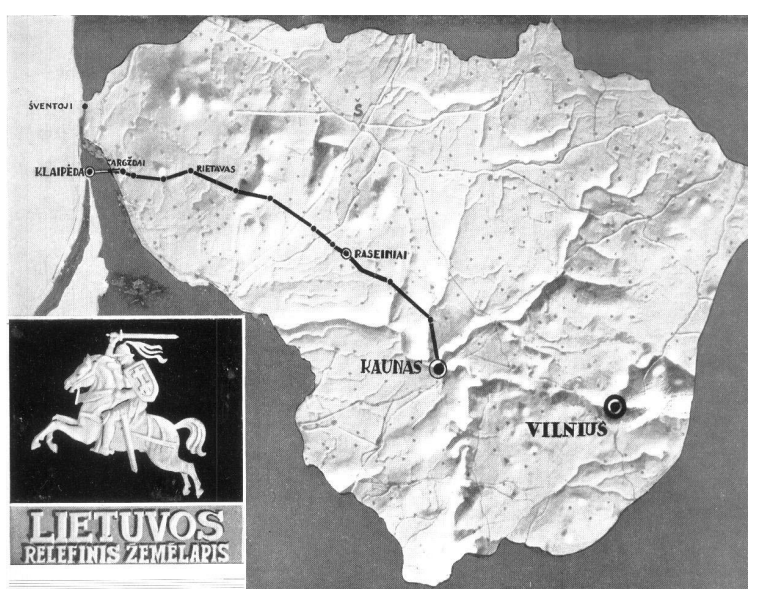

5 pav. Lietuvos reljefo modelis

Fig 5. Relief model of Lithuania
Kas šio reljefo modelio autorius ir modelio parametrai leidinyje nefiksuota, mums tik žinoma, kad iki Antrojo pasaulinio karo pradžios jis buvo Lietuvos susisiekimo ministerijoje.

\section{7. Žemètvarkos instituto Lietuvos reljefo žemėlapis}

Lietuvos reljefo M 1:300 000 žemèlapis (6 pav.) sudarytas Valstybinio žemètvarkos instituto Kauno kartografijos skyriaus, kuriam daugeli metu vadovavo Vaclovas Melisiakas (1929-1994), darbuotoju pastangomis. Keleto žemèlapių, kuriuos rengè kartografijos skyrius, mastelis buvo priderintas prie jau turimo matematinio ir geografinio pagrindo. Reljefo žemèlapiui buvo nusistatytas $20 \mathrm{~m}$ horizontaliu laiptas, aukščiu juostoms spalvinti - net 16 atspalvių aukščiu skalè, todèl žemėlapis gana spalvingas. Sudarant žemèlapi naudotasi sovietiniais topografiniais M 1:100 $000-1: 200000$ žemėlapiais. Lietuvos užribio teritoriją žemėlapių lapuose stengtasi užpildyti scheminiais žemèlapiais iš LTSR atlaso (polinkio kampai, geomorfologinis žemėlapis) ar naujai sudarytais pagal žinomų hidrografų ar geografų duomenis (upių baseinai, ortografinis skirstymas). Žemèlapyje lokalizuoti ir ivvardyti aukščiausieji ir žemiausieji taškai.

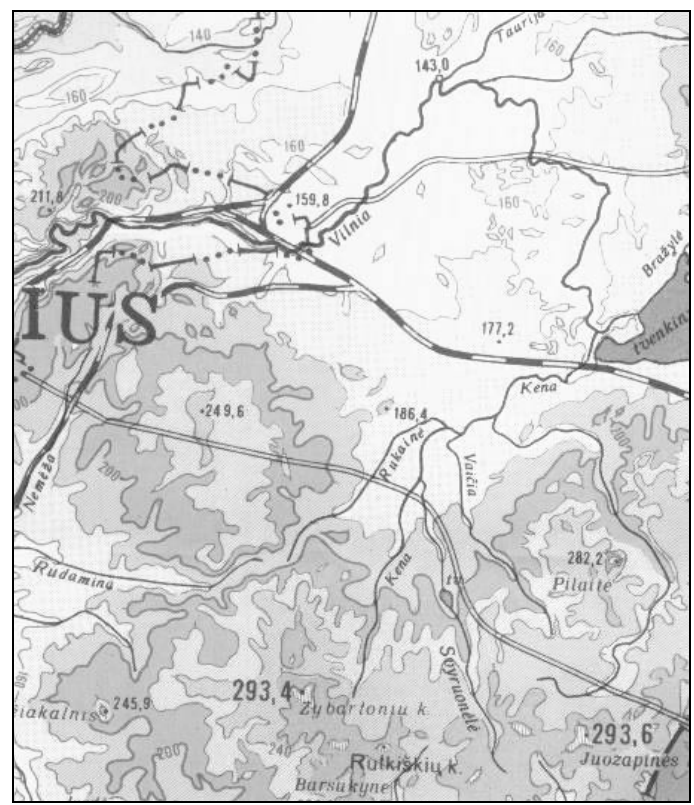

6 pav. Lietuvos reljefo M 1: 300000 žemėlapio fragmentas. RŽPI, 1990

Fig 6. Fragment of relief map of Lithuania 1: 300 000. RŽPI, 1990

Legendoje teikiama lentelè su duomenimis apie aukštumu viršukalves. Žemèlapis sudarytas 1988 m., 1990 metais atspausdintas Rygoje „Latvijos karte“ dviejuose $70 \times 110 \mathrm{~cm}$ sugretinamuose lapuose.

\section{V. Kvietkausko morfografinis žemėlapis}

Žemèlapis rengtas Lietuvos TSR atlasui (7 pav.). Tai sovietmečio produktas. Jo autorius Valdemaras Kvietkauskas (g. 1928) - geografas, ilgametis Lietuvos enciklopedijos leidyklos darbuotojas. 


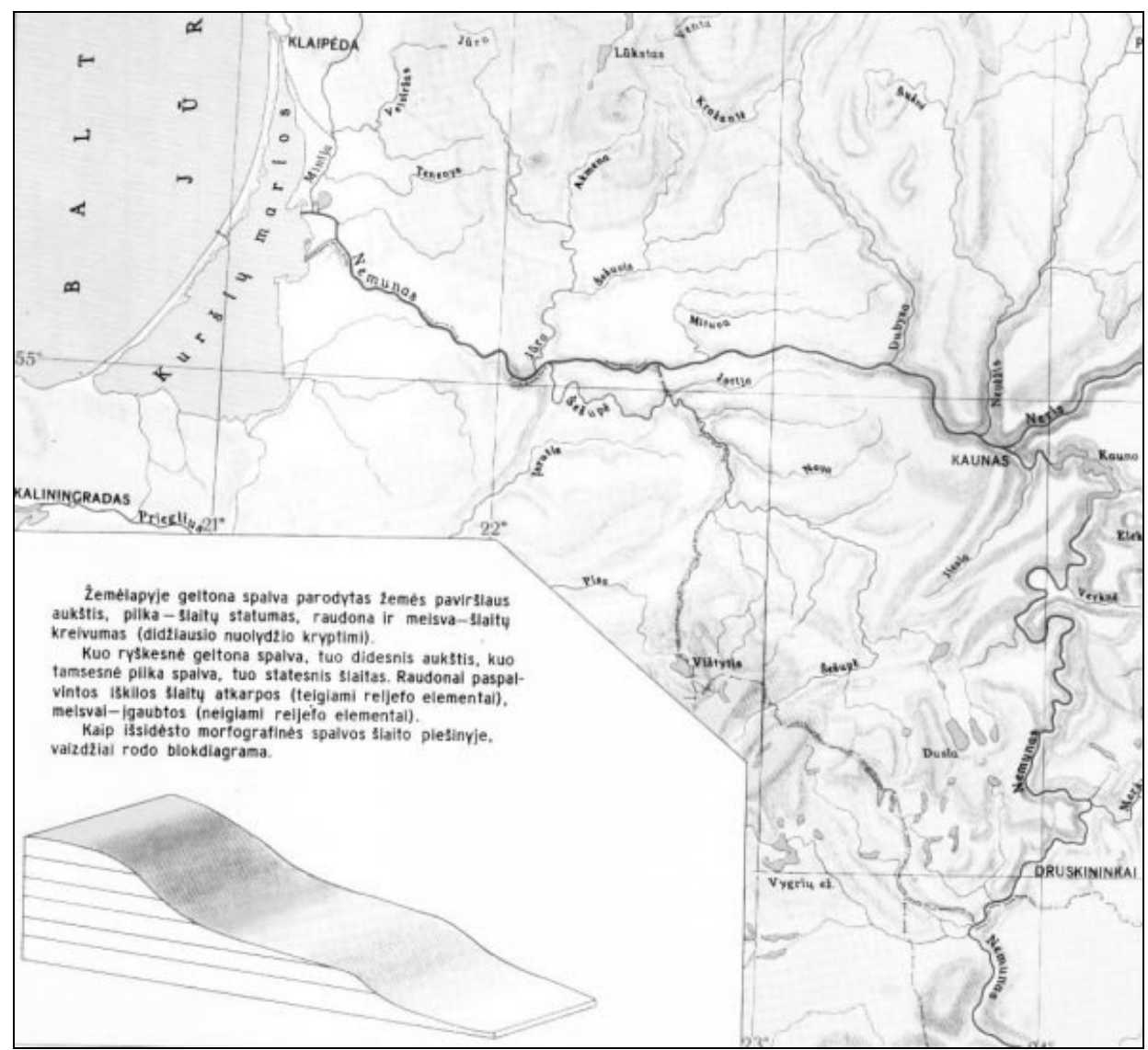

7 pav. Morfografinio žemèlapio fragmentas, M 1:500 000

Fig 7. Fragment of morphographic map 1:500 000

Reljefo skyriuje tai vaizdžiausias reljefo žemèlapis. Žymèta keturių spalvų metodu, reljefui atvaizduoti derinant kintamo intensyvumo spalvu fonus. Geltona spalva rodo absoliutuji aukšti, pilka - nuolydi, raudona išgaubtą, o mèlyna - igaubtą paviršiaus kreivumą. Manoma, kad šis metodas padeda detaliau pavaizduoti pakopas, lūžius, briaunas ir kt., ko neįstengiama išgauti izohipsių metodu [10].

\section{Distancinių tyrimu ir geoinformatikos centro reljefo modelis}

Lietuvai atgavus nepriklausomybę Vakarų Europos valstybès pradèjo teikti Lietuvai naujų technologiju diegimo, taip pat ir kartografijos reikmėms, pagalbą. Taip Lietuvą pasiekè skaitmeninès technologijos, pritaikytos kartografiniams produktams.

Distanciniu tyrimu ir geoinformatikos centras (GIScentras) - valstybès imonè, pirmoji Lietuvoje isisavino skaitmeniniu technologijų taikymą kartografinems reikmèms. Vienas iš pirmujų šio centro darbu - Lietuvos geoinformacinè duomenu bazè GDB 200, sukurta M 1:200 000 topografiniu žemèlapiu pagrindu. Šioje bazèje reljefo elementai teikiami dviem sluoksniais: horizontalemis ir aukščio bei vandens lygio tašku duomenimis [11]. $2001 \mathrm{~m}$. GIS-centras Lietuvos visuomenei pateikè populiarų šalies reljefo spaudinị su tų metų kalendoriumi (8 pav.).

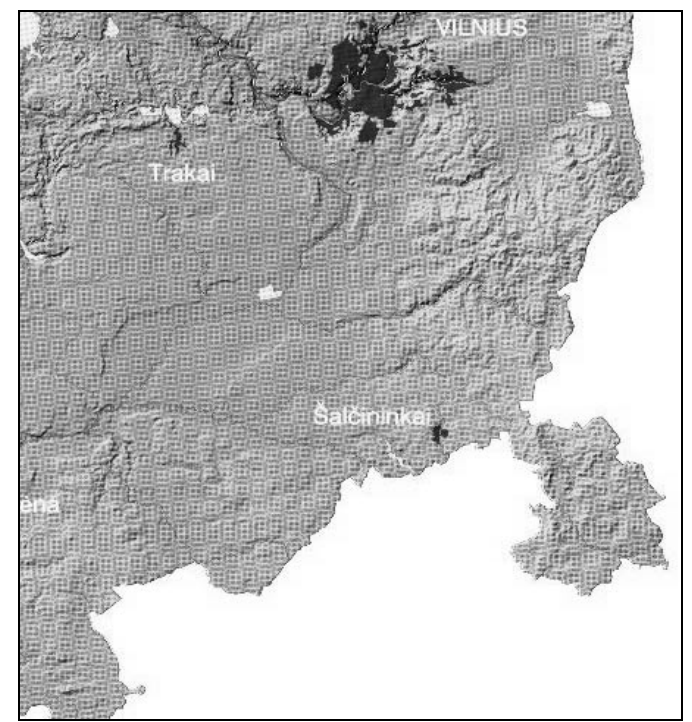

8 pav. Lietuvos reljefo modelio fragmentas, GIS-centras, 2001, M 1: 1000000

Fig 8. Fragment of relief model of Lithuania, GIS-centras, 2001, 1:1000 000

Nenurodytas šio spaudinio mastelis yra 1:1000 000. Reljefas žymimas kaitaliojant žalsvos gelsvos spalvos intensyvumą, iškilias reljefo vietas išreiškiant pagal istrižinio apšvietimo dèsnius ir taip sudarant iškilumo ivaizdi. 


\section{Topografiniai žemèlapiai - detalūs reljefo dokumentai}

Reljefas topografiniame žemėlapyje - savitas vietoves elementas, išreiškiamas ne tik kontūru, bet ir aukščiais. Reljefo išskirtinumas akivaizdus jau Pirmojo pasaulinio karo laikotarpio dvispalviuose pagrindiniuose topografiniuose M 1:84 000 (rusu), 1:100 000 (vokiečiu) žemėlapiuose, kuriuose reljefui buvo skirta antroji (ruda) spalva. Nepaisant to, informacija apie reljefą imanoma tik analizuojant šlaitų kryptis, horizontalių žymėjimą ir skaitmenines Žemès paviršiaus reikšmes.

Reljefo nuotrauka - daugiausia darbo sąnaudų reikalaująs procesas, palyginti su kitų vietovès objektų nuotrauka. Žemèlapiams sudaryti pradejjus taikyti aeronuotrauką daugumos vietovès objektų nuotrauka labai supaprastèjo. Reljefui braižyti reikalinga išskirtinių parametru aeronuotrauka, sudètingiau ja apdoroti nustatant vietovès taškų aukščius lauke, o mišku plotams žymėti lieka tik antžeminis nuotraukos metodas. Todèl reljefo nuotrauka stambiuoju masteliu Lietuvos ištisinè teritorija tebuvo pavaizduota du kartus - carinès ir sovietų Rusijos.

Topografinis valstybinès reikšmès kartografavimas atliekamas stambiaisiais masteliais. Carinès Rusijos žymiausieji kartografai K. Tenneris ir F. Šubertas irodinèjo 1:21 000 kartografavimo mastelio su 2 sieksnių reljefo laiptu tikslingumą. Sovietu laikais Lietuvos teritorija pagrindinai kartografuota M 1:10 $000 \mathrm{su} 1 \mathrm{~m}$ ar $2(2,5) \mathrm{m}$ aukščiu laiptu, atsižvelgiant i krašto kalvotumą. Šių bazinių nuotraukų pagrindu buvo sudaroma daug kitų mastelių smulkesnių žemėlapių, juos kuriant paeiliui buvo atliekamas vietovès objektu, taip pat ir reljefo, generalizavimas. Iki Antrojo pasaulinio karo pagal bazines nuotraukas paprastai žemėlapiai nebuvo leidžiami, spausdinta tik smulkesnių mastelių žemèlapiai.

Lietuvą (be Klaipėdos krašto) įtraukus i Rusijos sudèti, 1819-1829 m. buvo padaryta M 1:21 000 pusiau instrumentinè Lietuvos teritorijos nuotrauka.

Reljefas žymètas brūkšniuojant, polinkio kryptys orientuojant brūkšnius, o polinkio kampas - brūkšnio storiu pagal Lèmano skalę. XIX a. pabaigoje ši kartografinė informacija nebeatitiko Rusijos reikmių, todèl $1882-1907 \mathrm{~m}$. M 1:21000 nuotrauka buvo kartojama iš naujo - atliekant instrumentinę ir reljefą braižant horizontalèmis. Ši nuotrauka laikytina pirmaja Lietuvos teritorijos instrumentine nuotrauka su horizontalèmis. Išleidžiant 2 sieksnių laipto M 1:84000 žemėlapius ji buvo tik perkelta, naudojama vokiečiu, latvių ir sovietu M 1:75 000-1:100 000 žemėlapiams sudaryti tarpukario laikotarpiu, tik modifikuojant reljefo laipto žymèjimus ir metrinę sistemą aukščiams reikšti. Ypatingai strateginèse kariniu požiūriu vietovėse buvo parengti M 1: 42000 žemèlapiai (9 pav.).

Tik po Antrojo pasaulinio karo padaryta nauja topografine stambiojo mastelio sovietų okupuotos Lietuvos teritorijos nuotrauka. Iš pradžių ji buvo daroma naudojantis menzula - ant balto pagrindo, o patobulejus aeronuotraukos galimybėms - fotoplanuose. Toki kartografavimą pradėjo Lietuvos topografai. Nutraukta trečdalis teritorijos. Vèliau dèl slaptumo šie darbai buvo atliekami tik specializuotų sovietų imonių.

Ši nuotrauka sovietmečiu buvo 2-3 kartus atnaujinta, tačiau reljefas tik perkeltas. Reljefo atžvilgiu ši padètis nepakitusi iki šiol, nes $2004 \mathrm{~m}$. baigti lietuviški M 1:50 000 Lietuvos teritorijos topografiniai žemèlapiai, reljefas juose - iš sovietinio žemėlapio.

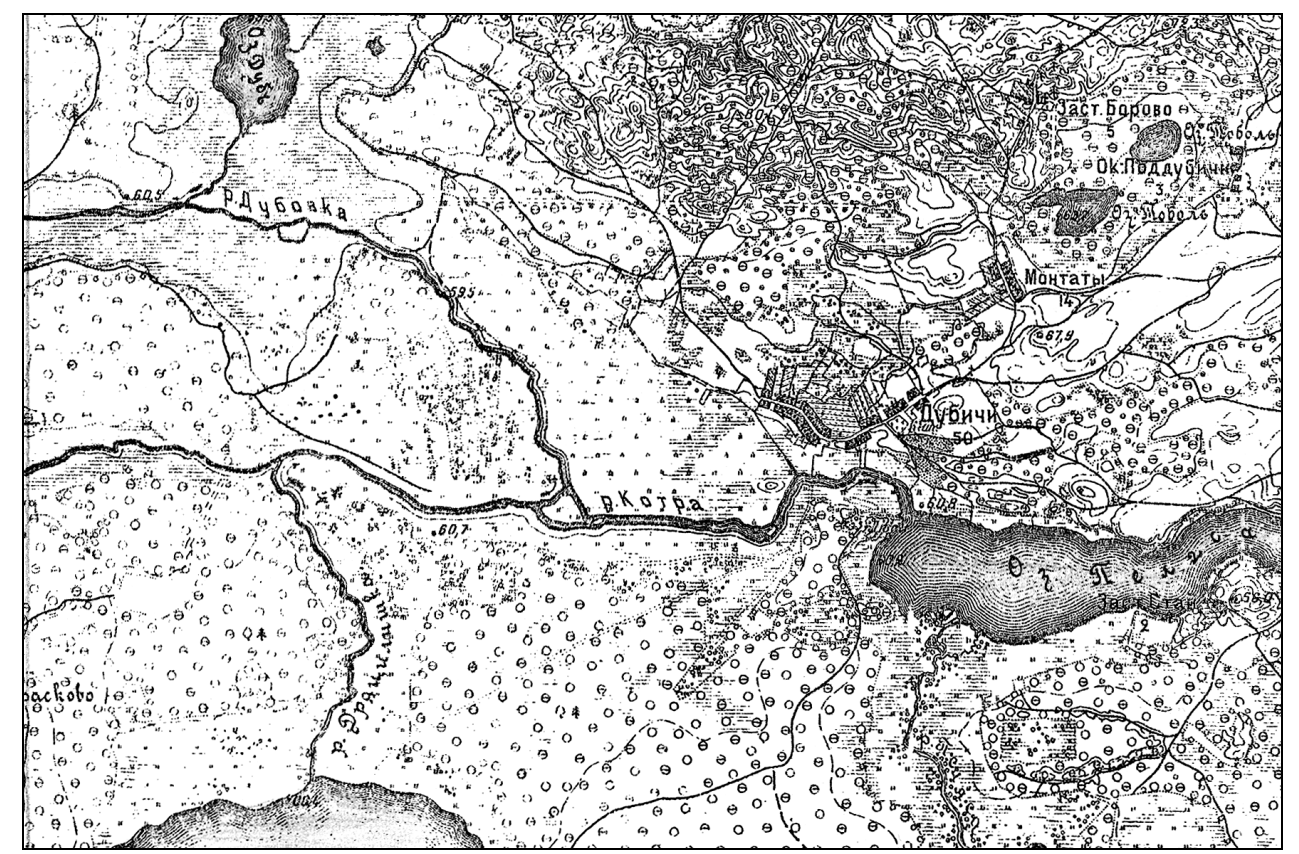

9 pav. 1: 42000 mastelio žemèlapio lapo LXXII-3, išleisto 1892 m., fragmentas

Fig 9. Fragment of map, page LXXII-3, scale 1: 42 000, 1892 


\section{Aerogeodezijos instituto Lietuvos reljefo žemèlapis}

Šis žemėlapis atspaustas $2005 \mathrm{~m}$. pradžioje 1:300 000 masteliu. Jo turiniui panaudota GDB 200 geoinformaciniu duomenų bazès versija 2.5. Vizualiai žemèlapis primena $1990 \mathrm{~m}$. Žemètvarkos instituto žemèlapi. Šie žemėlapiai tapatūs masteliu, aukščių laiptu ir dviem paskirties intarpais užrėmyje. Apžvelkime, kokie esminiai naujojo žemèlapio trūkumai ir privalumai, palyginti su pirmesniuoju.

Žemèlapis sutampa su valstybès sienos ribomis. Reljefo dariniai su administracinemis ribomis dažniausiai nesiejami, todèl paprastai reljefo žemèlapiai kuriami stengiantis pateikti pakankamai išsamu reljefo darinių vaizdą. Antra vertus, apsiribojus valstybės sienos ribomis, vertèjo pažymèti Baltijos jūros dugno reljefą. Kartografai pasiges informacijos apie žemèlapio kartografinę projekciją, jo aukščių ir koordinačių sistemas, oficialios informacijos žinovai pastebès upių baseinų pavadinimu neatitikimų, o autorių teisès saugotojai neras nuorodu apie kartografinius intarpus ir ežerų bei upių charakteristikų lenteles. Generalizacijos specialistai priekaištaus dèl hidrografijos elementų interpretavimo, nes kartografuotieji tvenkiniai dažnai žymèti be juos maitinančių upių.

Prie naujojo žemèlapio privalumų priskirtina turinio atnaujinimas ir tai, kad pažymėta gausiau $1 \mathrm{~m}$ tikslumu fiksuotu charakteringu vietovės žemès paviršiaus taškų. Antra vertus, reljefas per 15-20 metu ir jo $20 \mathrm{~m}$ laipto interpretacija iš esmès nepakito. Jo pokyčiui ịtakos galètú turèti tik didelès teritorijos statybų darbai arba stichijos padariniai. Pastebimi hidrografijos objektų pokyčiai, nes pažymėta daugiau tvenkinių, paminint pavadinimus, ir naujos generalizacijos upių tinklas. Žemėlapyje įbraižytas geografinis tinklelis, kurio nebuvo ankstesniajame žemèlapyje dèl sovietinio laikotarpio slaptumo nuostatu. Žemėlapis yra puikios poligrafinès kokybės ant gerą prekinę išvaizdą teikiančio pagrindo. Tai lèmé kartografinès ir poligrafinès skaitmeninès technologijos, įdiegtos žemèlapio sudarytojo ir spaudejo imonèse.

\section{Išvados}

1. Ivairius Lietuvos reljefo kartografinius produktus renge skirtingų profesijų atstovai, nes Žemès paviršiaus svarba ivvairiose Žemès paviršiaus formu, ju pasiskirstymo ir išraiškos tyrimų srityse yra pirmaeilè.

2. Paanalizavus reljefą kartografiniuose dokumentuose, matyti, kad reljefo išraiškai tiesiogiai ar per tarpinius leidinius naudota topografinès nuotraukos informacija.

Lietuvos ištisinès teritorijos reljefo instrumentinè topografinè nuotrauka daryta tik du kartus - iki Pirmojo ir po Antrojo pasaulinių karų.

3. Reljefas Lietuvos kartografiniuose leidiniuose, atsižvelgiant i jų laidos laikotarpi, iš esmès yra reljefo, pateikto pirmojoje arba antrojoje topografinejje nuotraukoje, interpretacija.
4. Šiuolaikinès kartografinès ir poligrafinès skaitmeninès technologijos leidžia parengti ir spausdinti puikios poligrafinès kokybės reljefo žemėlapius.

5. Aerogeodezijos instituto Lietuvos reljefo žemèlapyje tikslinga nurodyti pagrindinius metaduomenis iš skaitmeninių duomenų bazių. Tai atitiktų kartografijoje priimtas užrėmio informacijos tradicijas.

\section{Literatūra}

1. Sališčev, K. A. Fundamentals of cartoghraphy (Основы картографии). Moscow: MBG and K, 1944. 366 p. (in Russian).

2. Chomskis, V. Cartography (Kartografija). Vilnius: Mokslas, 1978. 336 p. (in Lithuanian).

3. Samas, A. Maps and its creators (Žemèlapiai ir jų kūrèjai). Vilnius: Institute of scientific and encyclopedia editions, 1997. 197 p. (in Lithuanian).

4. Matulionis, P. Land of Lithuanians and Letts. Map of relief (Lietuvių ir latvių žemè. Reljefinis žemėlapis). Tilžè: Publishing house of Reylender and son, 1922. 17 p. (in Lithuanian).

5. Lithuania on the maps (Lietuva žemèlapiuose). Catalogue of exhibition of 1999. Vilnius: Library of national museum of Lithuania, 2001, 152 p. (in Lithuanian).

6. Krikščiunas, A. History of surveying and cartography of Lithuania. Our reference book (Müsu žinynas), Vol XIV, No 40, 1928, p. 2-19 (in Lithuanian).

7. Kolupaila, S. Maps of Lithuania and neighbours. Our reference book (Mūsu žinynas), Vol XX , No 71, 1931, p. 81-87 (in Lithuanian).

8. Krikščiūnas, A. Map of Lithuania, scale 1: 400 000. Our reference book (Mūsu žinynas), Vol XXVI, No 106, 1934, p. 58-60 (in Lithuanian).

9. Butavičius, A. (editor) Highway of Lowlanders in 1939 (Žemaičiu plentas, 1939). Kaunas: Edition of the Roads Board, 1940. 47 p. (in Lithuanian).

10. Atlas of Lithuanian Soviet Republic (Lietuvos TSR atlasas). Moscow: MBG and K, 1981, p. 49, 52 (in Lithuanian).

11. Geoinformatic data basis of Lithuania GDB200 (Lietuvos geoinformacinè duomenų bazė GDB200). Vilnius: GIScentras, 1999. 22 p. (in Lithuanian).

Romualdas Girkus. Chief specialist for heritage. Institute of Aerogeodesy ( $\mathrm{Ph}+370$ 37451504).

A graduate of Kaunas Polytechnic Institute (now Kaunas University of Technology), geodetic engineer, 1962. Publications: over 20 scientific articles; participant of conferences in Latvia, Russia.

Research interests: history of geodesy and cartography.

Viktoras Lukoševičius. Doctor, Associate Professor. Dept of Civil Engineering Technique, Panevěžys Institute, Kaunas University of Technology ( $\mathrm{Ph}+370$ 45435819, fax +370 45516161).

A graduate of Kaunas Polytechnic Institute ( now Kaunas University of Technology), geodetic engineer, 1962. Doctor' s degree at Institute of Surveying, Aerial Photography and Cartography, Moscow, 1966. Publications: over 60 scientific articles; participant of conferences in USA, Brazil, Sweden, Norway, Russia. Fellowship Winner, NATO and Italy National Science Competition, 1996. Member of Association for the Advancement of Baltic Studies.

Research interests: history of geodesy and cartography. 